\title{
Mulheres que vivem com HIV/Aids: narrativas sobre violências em forma de cotidiano
}

\author{
Renata Alves César Fernandes ${ }^{1}$ \\ Evandro Alves Barbosa Filho ${ }^{2}$ \\ Ana Cristina de Souza Vieira ${ }^{3}$
}

\begin{abstract}
Resumo
$\mathrm{O}$ artigo analisa experiências de violência vividas por mulheres soropositivas. O estudo se fundamentou em feministas materialistas e estudiosos críticos do campo de HIV/Aids. A pesquisa de campo ocorreu em 2020, em hospital universitário, em Pernambuco. Nas aproximações à realidade e construção do corpus do estudo, foram realizadas entrevistas em profundidade, análise documental, observação, registro em diário de campo e revisão bibliográfica. As nove entrevistadas narraram cenários de violência, vivenciadas em unidades de saúde e em casa, praticadas por profissionais de saúde e companheiros, em situações que materializavam sua condição de subalternidade dentro da estrutura cisheteropatriarcal capitalista e sorofóbica.
\end{abstract}

Palavras-chave

Violência. Mulheres. HIV/Aids. Gênero.

Women living with HIV / AIDS: narratives about violence in form of daily life

\begin{abstract}
The article analyzes experiences of violence faced by HIV-positive women. The study was based on materialistic feminists and critical authors in the field of HIV/ AIDS. The field research took place in 2020, at a university hospital in Pernambuco. In the approach to reality and construction of the study corpus, in-depth interviews, document analysis, observation, recording in field diary and bibliographic review were carried out. The nine interviewees narrated scenarios of violence, experienced in health facilities and at home, practiced by health staff and partners, in situations that materialized their condition of subordination within the capitalist and serophobic cisheteropatriarcal structure.
\end{abstract}

Keywords

Violence. Women. VHI/SIDA. Gender.

Artigo enviado em maio de 2021

Artigo aprovado em agosto de 2021 


\section{Introdução}

O presente artigo analisa as violências e estigmas vivenciados por muIheres que vivem com HIV ou Aids. As diversas experiências de violência sofridas por mulheres soropositivas nos serviços de saúde e nas suas vivências extrainstitucionais foram relatadas durante pesquisa de campo, realizada em um hospital universitário no Recife, Pernambuco, com a autorização de comitê de ética em pesquisa ${ }^{4}$, no ano de 2020, com nove (9) ${ }^{5}$ mulheres vivendo com HIV/Aids, atendidas na unidade de saúde.

A necessidade de problematizar as violências de gênero enfrentadas por mulheres soropositivas é urgente, pois a violência pode ser um dos fatores que dificultam a vinculação das usuárias aos serviços de saúde, afetando a adesão e continuidade do tratamento, que, além do uso correto e contínuo dos antirretrovirais, demanda a realização permanente de exames e procedimentos para acompanhar a carga viral e as implicações da sorologia positiva sobre a saúde biológica e mental.

No que se refere ao percurso metodológico, foram utilizados procedimentos e técnicas qualitativas, como entrevistas em profundidade com mulheres soropositivas usuárias da unidade saúde onde foi realizada a pesquisa de campo. Diante da natureza crítica do estudo, a amostra foi não probabilística. Também foi realizada observação simples no serviço de saúde especializado em HIV/Aids e registro do cotidiano institucional em diário de campo. Nos processos de preparação que antecederam as entrevistas, foi realizada análise documental. Por meio dessa técnica, foram levantados e caracterizados os protocolos de tratamento, os prontuários sociais e as formas de organização da unidade de saúde e da rede para oferta (ou não) de tratamento biopsicossocial para HIV e Aids.

O corpus da pesquisa foi analisado com base no trabalho de feministas materialistas, como Silvia Federici, Heleieth Saffıoti e Verônica Ferreira, e de pesquisadores críticos do campo de HIV/Aids, como Ana Cristina de Souza Vieira, Solange Rocha, Raquel Soares e Evandro Barbosa Filho. Esse marco teórico e conceitual de análise foi formulado por meio de revisão bibliográfica. 
Por conta da filiação crítica dos autores deste artigo, a premissa é de que as experiências das entrevistadas são significadas/analisadas não só como experiências de indivíduos, ou de um grupo social estigmatizado e supostamente monolítico, mas também como experiências coletivas que cristalizam o lugar que elas concomitantemente ocupam nas estruturas sociais de classe, raça-etnia e gênero, sendo mulheres e soropositivas.

No Brasil, no período de 1980 a junho de 2020, foram detectados 1.011.617 casos de Aids ${ }^{6}$, de acordo com o Boletim Epidemiológico de HIV/Aids (BRASIL, 2020). Em relação às mulheres vivendo com $\mathrm{HIV}^{7}$, no período de 2007 a 2020, foram notificados no Sistema de Informações de Agravos de Notificação (SINAN) cerca de 104.824 nesta condição e entre os homens foram 237.551 casos (BRASIL, 2020). Na década de 2000, identificou-se uma elevada pauperização do(as) usuários(as) que acessavam os serviços especializados em HIV/Aids (SOARES et al., 2018). A partir desse período, a soropositividade deixou de ser uma condição quase que exclusiva de gays e homens que fazem sexo com homens $(\mathrm{HSH})$, brancos, pertencentes às classes médias e elites urbanas das regiões Sul e Sudeste, e passou a atingir uma população muito mais diversa de homens e mulheres urbanos e rurais, majoritariamente provenientes das frações mais pauperizadas da classe trabalhadora, e tendo novos casos se concentrando nas duas regiões mais pobres do país: Norte e Nordeste (BARBOSA FILHO; ROCHA, 2018; ROCHA et al., 2020). Desde esse momento, parte relevante das pessoas vivendo com HIV/Aids e que obtinham o tratamento por meio do SUS já estavam inseridas de forma ultraprecária no mercado de trabalho - em atividades informais, sem proteção previdenciária e com baixa remuneração média (SOARES et al., 2018).

No que se refere ao recorte racial e de gênero, é importante destacar que há um aumento sistemático referente à desigualdade e ao avanço crescente do HIV e da Aids entre mulheres, e "elas têm rosto: são jovens, negras e pobres” (ROCHA et al., 2018, p. 363). Rocha 
(2011b, p. 57-58) analisa que "no tocante à questão racial, enfrentam a perversa associação entre as desigualdades de classes e as dimensões relacionadas à autoestima, ao preconceito no serviço de saúde, às desigualdades nas relações interraciais [sic]". São essas mulheres que apresentam uma expressiva taxa de crescimento de mortalidade e abandono do tratamento (VIEIRA, 2018).

É necessário levar em consideração que há diferença nos óbitos ocorridos de acordo com os quesitos raça/cor e gênero, ou seja, muIheres negras sofrem maior impacto da Aids, tendo um índice maior de mortalidade (BRASIL, 2019, p. 13). Essas questões são importantes para dar visibilidade à pluralidade de trajetórias de vida e relações de poder veladas pelos números sobre a epidemia de HIV/Aids no Brasil. Além disso, as particularidades da experiência da soropositividade entre mulheres precisam assumir centralidade no debate, já que as mulheres no Brasil são as mais atingidas pela pobreza, pelo desemprego e pelas diversas formas de violência: estrutural, psicológica, material, política, física, etc., fatores reconhecidos de vulnerabilidade ao HIV e à Aids (ROCHA et al., 2020).

Embora a pesquisa que deu origem a este artigo tivesse como objeto central as implicações da soropositividade nos processos de cuidado e (auto)cuidado das mulheres; a frequência e a diversidade das situações de violência; as implicações dessas experiências na produção de estratégias de cuidado e autocuidado, relatadas pelas entrevistadas; assim como a escassez de literatura que abordasse os imbricamentos entre violências e vivência de mulheres soropositivas, foi necessária uma análise mais profunda desse fenômeno múltiplo, conforme exposto, mas não esgotado, nas seções que seguem.

\section{Violência no Brasil: expressão das desigualdades de gênero e raça}

A perseguição das mulheres é acentuada no cotidiano por meio das ideologias de desvalorização feminina, do elevado aumento da violência e do avanço dos discursos religiosos acerca do controle sobre 
a vida e o corpo. No Brasil, é possível verificar o aumento da desigualdade social e de gênero, da violência, dos casos de feminicídios e do discurso retrógrado institucionalizado por parte do atual governo do presidente Jair Bolsonaro por meio do seu Ministério da Mulher, da Família e Direitos Humanos, pensado para ter uma "centralidade conservadora da manutenção do tradicional conceito de família (pai, mãe e filhos), com o foco na tradição judaico-cristã na discussão sobre políticas públicas relacionadas a direitos" (FERREIRA, 2019).

A violência no país tem crescido no decorrer dos anos, apresentando diferenças entre as cinco regiões brasileiras, com crescimento acentuado no Norte e Nordeste, conforme o relatório intitulado Atlas da Violência 2019, elaborado pelo Instituto de Pesquisa Econômica Aplicada (Ipea) e Fórum Brasileiro de Segurança Pública (FBSP). Segundo o relatório, em 2017 ocorreram 65.602 homicídios no Brasil, o que equivale a uma taxa de 31,6 mortes para cada 1.000 (um mil habitantes), o maior nível histórico de letalidade violenta intencional do país. Esse estudo, que evidencia a expressiva dimensão da violência no país, também aponta o aumento da violência letal contra populações específicas, incluindo negros, população LGBTI (lésbicas, gays, bissexuais, travestis, transexuais, pessoas trans e intersexuais), e contra mulheres, especialmente os casos de feminicídio (IPEA; FBSP, 2019).

Essas populações, além de signifıcativamente impactadas pela violência, no Brasil também formam as chamadas "populações-chave", pois, a partir das desigualdades de poder do cis-heteropatriarcado capitalista, são as mais vulnerabilizadas ao HIV/Aids e outras Infecções Sexualmente Transmissiveis (ISTs) no país. Por exemplo, entre mulheres transexuais, a prevalência de HIV chega a 33,1\%, contra 0,5\% da população em geral; e o Brasil é o país que mais mata transexuais e travestis no mundo (ROCHA et al., 2020).

Ainda em relação aos crimes cometidos contra as mulheres, entre 2007 e 2017 houve um crescimento de 30,7\% no número de homicídios no país. Em 2017, o Atlas da Violência identificou um crescimento 
desse tipo de crime, com o número de 4.936 mulheres mortas - cerca de 13 mulheres assassinadas por dia, o maior número registrado desde 2007 (IPEA; FBSP, 2019). O referido documento analisa que 28,5\% dos homicídios ocorrem no domicílio (39,3\%, se não consideramos os óbitos cujos locais dos incidentes eram ignorados). Para o Atlas 2019 (IPEA; FBSP, 2019), provavelmente esses são casos de feminicídios íntimos, que decorrem da violência doméstica.

Fica evidente no cotidiano que há uma sensação de vulnerabilidade entre as mulheres e outros grupos atingidos em maior proporção pela violência. Há o medo cotidiano de sofrerem atos machistas e/ou homofóbicos, agressões verbais, psicológicas e físicas, com reforço dessa situação, inclusive por parte das instituiçõos de segurança e saúde, que, por vezes, naturalizam a violência e culpabilizam as mulheres e as minorias pelas diversas situações de violência que enfrentam, (re)produzindo discursos moralistas, tuteladores e culpabilizantes das vítimas.

A violência contra as mulheres, aqui entendida como uma expressão multifacetada da desigualdade de gênero e do patriarcado, vem crescendo estatisticamente no Brasil. O relatório da Organização Não Governamental (ONG) Human Rights Watch (2019) aponta uma epidemia nacional de violência contra as mulheres. Apesar da Lei Maria da Penha (Lei Federal N. ${ }^{\circ} 11.340$ de 2006) ser considerada bastante avançada no combate aos diversos tipos de violência contra as muIheres, existe uma precarização crescente nos serviços e na infraestrutura da rede de proteção social para o atendimento das mulheres em situação de violência.

No que se refere ao recorte por raça/cor, a taxa de homicídios entre mulheres não negras teve crescimento de 4,5\% entre 2007 e 2017 , enquanto a taxa de homicídios de mulheres negras cresceu 29,9\%. Em termos absolutos, a diferença ainda é mais brutal, já que entre não negras o crescimento é de 1,7\%, e entre mulheres negras é de $60,5 \%$ (IPEA; FBSP, 2019), caracterizando o imbricamento das desigualdades de gênero e raciais como alarmantes. As mulheres negras no Ociden- 
te, historicamente, sofreram vários tipos de violência com base na sua raça/etnia, nas assimetrias de gênero e pelo fato de pertencerem às frações mais subalternizadas da classe trabalhadora.

A exploração sexual em massa das mulheres negras escravizadas era uma consequência direta da política antimulher do patriarcado colonial da América. Dado que a mulher negra não era protegida nem pela lei ou opinião pública, ela era um alvo fácil. Enquanto o racismo foi claramente a maldade que decretou que o povo negro seria escravizado, foi o sexismo que determinou que o destino das mulheres negras seria duro, mais brutal do que o dos homens negros escravizados (HOOKS, 2014 p. 32).

Como expressão dessa opressão que não foi superada com o fim do regime colonial e do escravismo, sendo complexificada pela generalização da sociabilidade capitalista e do chamado "trabalho livre", o discurso conservador contemporâneo tem articulado racismo, religiosidade, neoliberalismo, irracionalismo e patriarcado, promovendo a naturalização das diversas violências praticadas contra as mulheres (BROWN, 2019).

Os mais afetados por essa restauração conservadora promovida pela coalizão entre atores nacionais e internacionais do capitalismo tardio e governos de extrema direita são as mulheres, especialmente as negras e latinas, e as populações LGBTIs, que também são populações-chave para o enfrentamento da epidemia de HIV/Aids. Essas populações são as mais afetadas por processos observados no Brasil e em outras latitudes, como o ataque às políticas orientadas à efetivação dos direitos sexuais e reprodutivos e da agenda feminista e de equidade de gênero, e o desmonte de programas públicos de excelência no enfrentamento ao HIV/Aids, a exemplo do Programa Nacional de HIV/Aids. Este, diante das pressões de políticos e grupos conservadores, tem centralizado suas ações em atividades de orientação biomédica, como a oferta de antirretrovirais, de Profilaxia Pré-Exposição (PrEP) e Pós-Exposição (PeP) em detrimento das ações que o fizeram 
referência internacional até a década de 2000: a abordagem centrada nos direitos humanos, sexuais e reprodutivos, a ampla participação de usuários e movimentos sociais na gestão e produção dos programas e campanhas, a defesa da livre orientação sexual e a recusa aos programas ultraconservadores de prevenção, centrados na abstinência, na fidelidade e no sexo restrito ao casamento (BARBOSA FILHO; ROCHA, 2018; ROCHA et al., 2020).

Para as mulheres vivendo com HIV/Aids, esses processos sociais de desmonte dos direitos de cidadania e das políticas públicas que os efetivam têm implicações imediatas nas condições objetivas/materiais, mas também nas relações intersubjetivas com parceiros, familiares e profıssionais e instituições de saúde, deixando evidente os frágeis liames entre realidade objetiva e produção da subjetividade.

\section{Mulheres soropositivas: relatos sobre espaços, situações e agentes da violência}

As participantes da pesquisa relatam trajetórias de vida que cristalizam as tendências destrutivas das relações de classe, raça/etnia e gênero na atualidade. Elas têm idades variadas entre 27 e 52 anos, e em sua maioria se identificam como pardas ou negras, tendo apenas duas delas se autodeclarado branca e amarela. A única que tinha trabalho assalariado, ocupando um posto de trabalho formal na área de sua formação de nível superior, se identifıcava como parda. A única branca dependia da renda do padrasto e da mãe e se dedicava exclusivamente ao trabalho de cuidados com a filha; três das entrevistadas não tinham fonte de renda; três dependiam do Benefício de Prestação Continuada (BPC); uma recebia auxílio-doença do INSS e outra tinha por fonte de renda o Programa Bolsa Família.

A participante transexual tinha 43 anos, se identificava como negra e, além do BPC, contava com a renda oriunda do assalariamento do trabalho do marido, com quem mantinha um relacionamento há mais de 12 anos. A participante mais velha, 52 anos, se identificou 
como negra, tinha frequentado a escola até a $1^{\text {a }}$ série do ensino fundamental e contava exclusivamente com a renda do BPC. Nenhuma das entrevistadas teve um diagnóstico recente, com menos de um ano de descoberta da sorologia; aliás, todas as mulheres com diagnóstico recente, atendidas nessa unidade de saúde, se recusaram a participar da pesquisa. Tal postura, totalmente compreensível diante da mortificação e do estigma decorrentes da soropositividade, corrobora a literatura (ROCHA, 2018; VIEIRA et al 2018) que aponta que, nos momentos que se seguem à descoberta da sorologia, as atitudes mais comuns são de negação e/ou luto.

Mesmo as entrevistas ocorrendo em um ambiente protegido, reservado, no qual as participantes puderam falar sem interrupções, era possivel observar os olhares de desconfiança e o tom da voz, quase sussurrado, no início das conversas. O cuidado para mencionar menos possível o nome do vírus ou da doença foi manifesto por todas as participantes. O diagnóstico foi significado por todas como um acontecimento que mudou suas vidas: existe "um antes e um depois da descoberta da sorologia".

O medo da revelação do diagnóstico se estende, inclusive, para os membros da família. As entrevistadas revelam que se distanciaram total ou parcialmente de familiares e/ou amigos devido ao medo de que descubram sua sorologia, e consequentemente elas passem a sofrer discriminação. Esse achado da pesquisa corrobora os resultados do estudo realizado por Beloqui (2019), referente à violência e discriminação com Pessoas Vivendo com HIV/AIDS (PVHA), que revela que o estigma, o preconceito e a discriminação relacionados ao HIV e à Aids também estão presentes no cotidiano familiar. Essa pesquisa, primeiro estudo nacional sobre violência sofrida por PVHA, também aponta os tipos mais comuns de violência vivenciados por esses homens e mulheres no Brasil: violência familiar, institucional, física e psicológica. Mais de $30 \%$ dos sujeitos da pesquisa deixaram de se relacionar ou participar da vida familiar por medo de preconceito e discriminação. 
Tais dados são preocupantes, não só pelos impactos psicossociais do processo de fragilização e de ruptura de vínculos parentais e familiares, mas também pelo reconhecido "familismo" nas políticas sociais no Brasil, no qual não contar com o suporte familiar formal ou de provisão de cuidados aponta para um risco ampliado de vulnerabilidade social.

Mas nem as unidades de saúde, nem mesmo as instituições especializadas no atendimento em HIV/Aids, se apresentam como espaços livres de (re)produção de violência. As entrevistadas relataram situações que vão desde a revelação não autorizada da sorologia por médicos e outros profissionais de saúde, o que, além de infração ética, é crime, até o assujeitamento realizado por esses profıssionais, que, diante da soberania do saber-poder biomédico, não dialogam, não aconselham e não reconhecem as usuárias como as protagonistas dos seus tratamentos e da sua saúde.

[...] o médico falou o meu diagnóstico na frente das pessoas e as pessoas ficaram com um olhar diferente e me senti mal. Depois procurei o médico e na frente dos estudantes, para que eles aprendam, reclamei com o médico, disse que não poderia fazer isso. Ele me pediu desculpas. Às vezes, os profissionais de saúde falam e os outros pacientes que não têm ficam olhando, com medo de ir até no banheiro (E1, 27 anos, parda).

Busquei as informações! A verdade deles (dos médicos) é a verdade absoluta? E eu pesquisei sobre a doença. Meu direito fica onde? Por que sermão? Não tenho direito a escolher? A questão do HIV é como se fosse lepra, tem que se afastar, tem que fazer medicamento. Fiz tratamento por três anos e não tinha saúde, tive várias complicações (E2, 38 anos, branca).

Minha filha quando soube do diagnóstico, aquele oitavo andar (do Hospital) da Restauração, se não tivesse grade, eu tinha pulado. Isso foi em 2002. O médico chegou na sala, sentada, assim como estou conversando com você. Ele chegou na sala abriu a porta e disse: olhe, você está com Aids, você só tem um ano de vida. A pessoa fica atônica. Veio uma filmagem da minha vida todinha, aquela reviravolta, veio meus filhos, veio 
a minha mãe, um flash! Olhei para os quatro cantos, procurei um canto para me jogar e não encontrei. O jeito foi correr na Restauração, do oitavo andar até o sexto, gritando. Eu vi a hora o povo me amarrar! Gritando que eu ia morrer, ia morrer... e que eu não ia morrer assim! A gente via a história de Cazuza na televisão, como foi que ele ficou. Quando o homem chega na minha cara para dizer que eu estou com Aids, não era nem HIV positivo. Aids logo a doença! Você está com Aids e só tem um ano de vida. Esperava o quê? Só sei que uma enfermeira ligou para minha mãe. Minha mãe veio, minha irmã veio, a que trabalhava com médico. A minha irmã ameaçou de processar ele, só ficou na ameaça, devia ter processado. Eu ia comer dinheiro! O homem tinha quase três metros de altura, cavalo não, se amostrava! Que homem bruto. Aquele ali era cavalo batizado e renovado. Foi muito difícil para mim. la ser difícil não, é difícil para qualquer ser humano, você sabe, né? Até hoje você leva a sua vida adiante, mas é difícil (9E, 52 anos, negra).

Essas falas trazem um importante indicativo quanto à necessidade de qualificar a assistência em saúde, desde o acolhimento até a humanização na revelação da sorologia, e nos processos de aconselhamento, procedimento fundamental nas práticas de prevenção e assistência e parte integrante do tratamento para HIV/Aids no Brasil desde a década de 1990. Mas essa abordagem holística do processo saúde-doença vem perdendo espaço para a medicalização do tratamento e soberania do saber e dos insumos biomédicos (ROCHA et al., 2020). Além dessas barreiras, compartilhadas com outras PVHA, as mulheres também lidam com outras dificuldades, a exemplo da necessidade de ampliação de serviços que garantam o acesso aos direitos sexuais e reprodutivos, pois, a partir da sua sorologia, têm os direitos à vida sexual e afetiva e, especialmente, à gravidez e à maternidade negados.

Todos diziam que não tinha capacidade de cuidar da minha fiIha. A minha família e alguns profissionais da maternidade diziam isso. Parecia que eu não era mãe da minha filha. Fiz tudo! Parei de tomar meu remédio, o anticonvulsivo e tomava os remédios 
para HIV, à força, mesmo enjoada. Me sinto culpada por tudo. Eu fiz tudo! (E6, 35 anos, parda).

Descobri em 2003. Não me desesperei, fiquei rezando, se a pessoa se desesperar, se mata. O meu filho eu tive depois (do diagnóstico), a médica só faltou me matar. Tomava remédio a pulso, vomitava e minha mãe me obrigava a tomar. O meu filho nasceu bem. Trataram bem, só não gostei de uma enfermeira que falou o que eu tinha na frente das pessoas. Reclamei ao médico e ela foi afastada, porque me deu $10 \mathrm{ml}$ de antialérgico. Era para ser 5 $\mathrm{ml}$. Passei o dia dormindo. Não a vi mais. Mudaram a técnica de enfermagem. (7E, 42 anos, negra).

De acordo com Federici (2004), a criminalização do controle das mulheres sobre a procriação é um fenômeno cuja importância não pode deixar de ser enfatizada, tanto do ponto de vista de seus efeitos sobre as mulheres, quanto por suas consequências na organização capitalista do trabalho. Para dar continuidade a essas reflexões, é necessário desvelar o significado da violência e de sua naturalização, partindo da análise da sociedade capitalista, que tem em sua essência o patriarcado. Para tal, foi utilizada a concepção de violência formulada por Heleieth Saffioti:

[...] a ruptura de qualquer forma de integridade da vítima: integridade física, integridade psíquica, integridade sexual, integridade moral. Observa-se que apenas a psíquica e a moral situam-se fora do palpável. Ainda assim, caso a violência psíquica enlouqueça a vítima, como pode ocorrer - e ocorre com certa frequência, como resultado da prática de tortura por razões de ordem política ou de cárcere privado, isolando-se a vítima de qualquer comunicação via rádio, televisão ou qualquer contato humano -, ela torna-se palpável (SAFFIOTI, 2004, p. 17).

Dar visibilidade a essa definição possibilita enxergar a violência para além daquela que deixa apenas as marcas no corpo, assim como a necessidade de desnaturalizar e romper com o silêncio daquelas que estão em situação de violência. No intuito de alimentar o sistema cis- 
-heteropatriarcal capitalista, as mulheres são majoritariamente educadas para possuírem determinadas características: serem afetuosas, discretas e cuidadoras. Além disso, são treinadas para sentir culpa e socializadas para "sofrer", de acordo com Saffioti (2004). A violência contra as mulheres é indissociável das relações de gênero, que, para Saffioti (2004) e Federici (2004), correspondem à construção social do masculino e do feminino a partir das assimetrias de poder presentes na (re)produção das relações sociais, privilegiando os homens sobre as mulheres no mundo do trabalho assalariado e doméstico e na esfera da afetividade sexual.

Cinco das entrevistadas relataram situações de violência praticadas por ex-parceiros. A única mulher trans enfrentou diversas situações de violência de companheiros e clientes, enquanto trabalhou na prostituição. Elas entendem que a descoberta do status sorológico é utilizada por companheiros como justificativa para a prática de abuso e violência.

[...] eu já sofri muito, já tive muitos relacionamentos abusivos. Pessoas que eu queria levar a sério, mas não deu certo. Não sei se é falta de sorte, não sei o que é. As pessoas me enganam facilmente. Não só isso, minha mãe fica preocupada e me alerta: escuta, cuidado com as pessoas! Algumas pessoas têm preconceito quando descobre (a sorologia). Abusa da pessoa, aí como eu já tinha depressão, isso já mexe com a autoestima. Tem muita gente má no mundo (E6, 35 anos, parda).

De acordo com Saffioti (2004, p. 17), "a questão se situa na tolerância e até no incentivo da sociedade para que os homens exerçam sua força-potência-dominação contra as mulheres, em detrimento de uma virilidade doce e sensivel, portanto mais adequada ao desfrute do prazer".

Quando minha avó faleceu, fugi de casa e fui morar com o pai da minha filha. Passei 5 anos com ele, foi um relacionamento abusivo. Depois tentei me relacionar com um vizinho, ele era de um jeito e depois mudou. Era um relacionamento abusivo. Ele usava drogas, me agredia. Era outra pessoa. Senti diferença 
quando falei para meu namorado sobre o meu diagnóstico. Ele me deixou e a mãe dele começou a me discriminar. Foram violências de todas as formas. São seis meses de antidepressivos (E6, 35 anos, parda).

Como afırma Rocha (2011b, p. 57-58), “no tocante à questão racial, as mulheres que vivem com Aids enfrentam a perversa associação entre as desigualdades de classe e as dimensões relacionadas à autoestima, ao preconceito e à discriminação nos serviços de saúde". Sobre os episódios de violência que acompanham a descoberta/exposição da sorologia, a entrevistada E5 relata como descobriu sua sorologia no hospital em que trabalha. Desde então, passou por diversas violências sorofóbicas nesse espaço, como quebra de sigilo do diagnóstico, exposição não autorizada, discriminação, violência psicológica, entre outras:

[...] o exame foi aberto. O hospital soube todinho e eu fui a última a saber. Eu pensava até em me matar. Fui para a igreja, ficava escutando a palavra de Deus. Daqui a pouco passava perto de um carro e fazia, eu não mereço está nesse mundo. Eu morro de medo de ponte, aí cheguei junto da ponte assim... pensei: não vou levar esse pecado para Deus, não. É horrível e quando você passa, assim a única pessoa que eu tinha no momento era meu esposo que sabia, né? E o pessoal do hospital, que me olhava atravessado. Parecia uma coisa, na hora acontece tudo. Eu me cortei no prontuário, fiquei nervosa, aí passei a mão no prontuário, o sangue pelo chão. Aí a técnica de enfermagem, chama a menina da limpeza, chama a menina da limpeza e diz que não chegue junto do sangue dela! Aí eu disse, nem se eu tivesse com alguma coisa assim, infectocontagiosa que transmitisse pelo ar (E5, 42 anos, parda).

A análise documental das ações desenvolvidas pela unidade de saúde com as mulheres soropositivas identificou a centralidade da prevenção da transmissão vertical do HIV, quando a transmissão do vírus HIV ocorre na gestação, no parto ou na amamentação. Esses processos de trabalho em saúde, que fazem a interface saúde 
da mulher e materno-infantil, deveriam contemplar a saúde sexual e reprodutiva das mulheres.

Como afirma Rocha (2011b), em detrimento da ampliação de ações que possam garantir os direitos sexuais e reprodutivos das mulheres, objetivamente, constata-se que nas ações estão sendo relegados ao segundo plano os cuidados humanizados, o aconselhamento e o suporte às mães soropositivas. Segundo a autora, desde 2007 a estratégia nacional para diminuir a transmissão vertical do HIV se desdobrou, entre outras, nas seguintes ações: recomendação do teste de HIV para todas as gestantes atendidas nos serviços de saúde; treinamento das equipes de saúde; e acompanhamento clínico de gestantes soropositivas, com disponibilização de medicação. Nessa programática de saúde materno-infantil, foram marginalizadas a discussão sobre os direitos sociais, sexuais e reprodutivos das mulheres soropositivas, a quebra de estigmas em torno da sorologia e a desconstrução de estereótipos femininos, ações em saúde fundamentais para enfrentar o HIV e emancipar as mulheres.

A violência contra as mulheres se expressa de diversas formas, por meio das relações desiguais de gênero, que diariamente são reforçadas, seja pela omissão do Estado, pelo machismo praticado e naturalizado dentro da família e dos espaços de trabalho, pela falta de políticas públicas que garantam ao menos uma parte da agenda feminista, sobretudo para as mulheres socialmente mais vulneráveis (ROCHA et al., 2020). Entre as mulheres soropositivas, as múltiplas experiências de violência se imbricam e são complexificadas pela sorofobia e pelo estigma que as acompanham desde o cotidiano no ambiente doméstico até situações violadoras nas unidades de saúde.

O tratamento mudou a rotina. Uma pessoa normal é uma coisa, as pessoas que vivem com HIV é outra, porque remédio é constante, para onde você vai tem que levar a farmácia junto e tem muitos cantos que você chega, né? Não pode. Tem até receio de tomar medicação por causa das embalagens. Quando eu viajo, 
eu boto dentro de uma caixinha. O que é isso aí? Vitamina. Me dá uma? Pode não. Fora isso... (E9, 52 anos, negra).

Quem sabe do diagnóstico da pessoa tem nojo, medo de conviver com o outro. Não é o fim do mundo! Deveria ter mais respeito, desestigmatizar os soropositivos. Isso só prejudica, se torna humilhante, vergonha e constrangimento. Quando fiquei internada em outro hospital, os médicos falaram na frente ao meu acompanhante sobre o meu diagnóstico. E as pessoas fazem cara de espanto! Quando é câncer, ninguém faz cara de espanto. Falam que vai melhorar e faz cara de pena (E2, 38 anos, branca).

As mulheres que vivem com HIV/Aids e engravidam, principalmente aquelas que já tinham conhecimento sobre o diagnóstico antes da gestação, são continuamente culpabilizadas e alvo de violência institucional sorofóbica, praticada por profissionais de saúde. Rocha (2011a, p. 113) destaca que "a política de saúde é uma estratégia que deve romper com a concepção patriarcal que associa e identifica as mulheres com a maternidade e a reprodução", mas que a estrutura cis-heteropatriarcal se reproduz nas equipes e unidades de saúde, classificando as mulheres entre aptas/habilitadas e aquelas inaptas/ indesejadas para a maternidade.

Fui muito maltratada no parto, fiquei oito dias internada na maternidade. Fiz meu pré-natal no particular, mas não consegui fazer o parto. Tive que ir para o público. Não tive direito a nada! Não pude amamentar. Mesmo fazendo o que eles (os médicos) queriam, fui maltratada. Eles diziam: como sabia da doença e não tomei o AZT (antirretroviral). Minha filha nasceu no peso, bem, por não ter dado AZT. Não fizeram exame e entupiram a criança de remédio. Que mundo é esse? Se uma mulher grávida (sem HIV/Aids) não pode tomar nem um dipirona, por que eu tenho que tomar o AZT? Só conseguiria algum direito, se voltasse ao tratamento. Tive que me humilhar para voltar a fazer o tratamento. Não me deram medicação, e internaram logo! (E2, 35 anos, branca). 
Nesse sentido, observa-se que o imaginário coletivo sobre HIV/ Aids e a atitude da sociedade, e até dos profıssionais de saúde, fundamentados na sorofobia, reproduzem o discurso que classifica mulheres soropositivas como inaptas para a gravidez/maternidade, mesmo depois de décadas da criação de alternativas seguras de reprodução assistida, disponíveis também pelo SUS para mulheres e casais soropositivos ou sorodiferentes.

Essas tecnologias de reprodução assistida vão desde a fertilização in vitro, monitoramento contínuo da carga viral da gestante, até técnicas específicas de condução de parto natural ou cesariana que protegem o bebê de exposição ao sangue ou fluídos da mãe. Essas tecnologias, que também são direitos sexuais e reprodutivos das mulheres soropositivas, não põem em risco os bebês, mães e os parceiros ou parceiras. Mesmo assim, nenhuma das entrevistadas relatou ter recebido informações/aconselhamento sobre esses direitos, mesmo nos serviços especializados em HIV/Aids, ou quando expressaram o desejo pela experiência da maternidade biológica durante atendimentos realizados em outras unidades de saúde, especializadas ou não. Isso evidencia como uma verdadeira interdição dos corpos das mulheres soropositivas se processa dentro dos serviços de saúde, atendendo às hierarquias de gênero e saúde que determinam o processo de reprodução social.

\section{Considerações finais}

Como afirma Santos (2020, p. 12): “o patriarcado induz a ideia de estar moribundo ou enfraquecido em virtude de vitórias significativas dos movimentos feministas nas últimas décadas, mas, de fato, a violência doméstica, a discriminação sexista e o feminicídio não cessam de aumentar".

Além dos dados sobre a magnitude da violência no Brasil e como esse é um processo que reflete e refrata as desigualdades de classe, raça/etnia e gênero com implicações mais profundas para mulheres 
e populações LGBTIs, estudos recentes evidenciaram que viver com HIV ou Aids é um determinante na vulnerabilização de homens e muIheres à violência. No país, a violência contra soropositivos ocorre em diversos espaços, no familiar, no trabalho e de saúde, se expressando em violência institucional, verbal e psicológica, em exposição às situações vexatórias etc.

Nesse sentido, as participantes da pesquisa relataram que os dois cenários mais comuns de violência são as unidades de saúde e as suas casas. As experiências de violência nos serviços de saúde se deram desde o diagnóstico do HIV ou da Aids, em que a comunicação não ocorre de maneira acolhedora, sigilosa ou humanizada, até nas situações de gravidez, parto ou puerpério, em que as mulheres são culpabilizadas pela gravidez e pelo suposto risco a que expuseram o bebê. A falta de aconselhamento em saúde sobre direitos sexuais e reprodutivos acerca do tratamento e suas implicações e os meios de acesso às tecnologias de gravidez assistida também deve ser caracterizada como uma violência praticada por omissão de instituições e profıssionais de saúde.

Os relatos das entrevistadas apontam que os processos de trabalho em saúde têm reproduzido estigmas e práticas controladoras e punitivas sobre as mulheres soropositivas. As violências praticadas por trabalhadores da saúde não podem ser analisadas apenas pelo viés da particularidade, centradas na singularidade das experiências e das narrativas, descoladas de uma conjuntura. Essas práticas de saber-poder evidenciam o fortalecimento de uma racionalidade e discurso conservadores, baseados no modelo biomédico, que nega a concepção ampliada de saúde.

As entrevistadas também narraram várias situações de violências psicológica, verbal e física exercidas por seus parceiros. Os relatos não diferem muito dos apresentados por outras mulheres vítimas do patriarcado, mas o fato de a sorologia delas ser utilizada como fator iniciador ou intensificador da ação dos parceiros agressores é algo pou- 
co descrito na literatura. Essa questão, que cristaliza o imbricamento de patriarcado e sorofobia, precisa ser objeto de novas pesquisas e intervenções, já que a violência patriarcal pode funcionar como um importante fator de abandono ou de não adesão ao tratamento. As falas, os silêncios e até as negativas das entrevistadas em se aprofundar em determinados temas evidenciam que o patriarcado segue potente, uma força estruturante de seus cotidianos, e que suas implicações deletérias são ampliadas quando, além de mulher, se é soropositiva.

\section{Referências}

BARBOSA FILHO, Evandro Alves; ROCHA, Solange. Três décadas de neoliberalismo e de lutas contra a epidemia de HIV e Aids na periferia capitalista: Uma análise crítica da África do Sul, Brasil e Moçambique. In: ROCHA, S.; VIEIRA, A. C. de S.; BARBOSA FILHO, E. A. HIV AIDS e as teias do capitalismo, patriarcado e racismo: África do Sul, Brasil e Moçambique. Recife: EdUFPE, 2018, p. 27-156.

BELOQUI, J. A. Brasil: Violência e Discriminação em Pessoas Vivendo com HIV/AIDS. A perspectiva dos membros da RNP+. São Paulo: Rede Nacional de Pessoas Vivendo com HIV e AIDS (RNP+); Grupo de Incentivo à Vida (GIV), 2019. Disponivel em: http://giv.org.br/Arquivo/Relatorio-RNP-Brasil-Violencia-Discriminacao-Pessoas-HIV-Aids.pdf. Acesso em: 5 ago. 2020.

BRASIL. Ministério da Saúde. Boletim Epidemiológico de HIV/AIDS 2020. Brasília: 2018. Disponível em: < http://www.aids.gov.br/pt-br/pub/2020/ boletim-epidemiologico-hivaids-2020>. Acesso em: 10 dez. 2020.

BROWN, Wendy. Nas Ruínas do Neoliberalismo: a ascensão da política antidemocrática no Ocidente. São Paulo: Filosófica Politeia, 2019.

FEDERICI, S. Calibã e a Bruxa: mulheres, corpo e acumulação primitiva. Tradução do Coletivo Sycorax. São Paulo: Elefante, 2004. Disponível em: http:// coletivosycorax.org/wp-content/uploads/2019/09/CALIBA_E_A_BRUXA_ WEB-1.pdf. Acesso em: 12 set. 2018.

FERREIRA, L. Governo Bolsonaro tem início com pasta dos Direitos Humanos hiperconectada a discurso evangélico. Revista Eletrônica Gênero e Número, 2019. Disponível em: http://www.generonumero.media/governo-bolsonaro-tem-inicio-com-pasta-dos-direitos-humanos-hiperconectada-discurso-evangelico/. Acesso em: 15 jan. 2020. 
HOOKS, B. Ain't a woman: black woman and feminism. $1^{\text {a } e d . ~ T r a d u c ̧ a ̃ o ~ L i-~}$ vre para a Plataforma Gueto, 2014. Disponível em: <https://plataformagueto. files.wordpress.com/2014/12/nc3a3o-sou-eu-uma-mulher_traduzido.pdf>. Acesso em: 23 jul. 2018.

HUMAN RICHTS WATCH (HRW) World Report 2019: events of 2018. Disponivel em: https://www.hrw.org/sites/default/files/world_report_download/ hrw_world_report_2019.pdf. Acesso em: 15 jan. 2020.

IPEA; FBSP. Atlas da Violência 2019. Brasília: Rio de Janeiro: São Paulo: Instituto de Pesquisa Econômica Aplicada; Fórum Brasileiro de Segurança Pública, 2019. Disponível em: <https://www.ipea.gov.br/portal/index.php?option=com_content\&view=article\&id=34784\&ltemid=432>. Acesso em: 13 jan. 2020.

ROCHA, S. Lutando por mais saúde: movimento feminista contra a epidemia de AIDS. In: ROCHA, S.; VIEIRA, A.; SOARES, R. (org.). Desafios à Vida: Desigualdades e HIV/AIDS no Brasil e na África do Sul. Recife: Ed. Universitária da UFPE, 2011a. p.100-116.

ROCHA, S. Silenciosa conveniência entre transgressão e conservadorismo: trajetórias feministas frente a epidemia da AIDS no Brasil. 2011. $281 \mathrm{f}$. Recife: UFPE, 2011b. Tese (Doutorado em em Serviço Social) - Programa de Pós-Graduação em Serviço Social, Universidade Federal de Pernambuco (UFPE), Recife, 2011b.

ROCHA, S. et al. Mulheres, HIV e AIDS: os silêncios e as vozes no Brasil, África do Sul e Moçambique. In: In: ROCHA, S.; VIEIRA, A.; ALVES FILHO, E. HIV AIDS e as Teias do Capitalismo, Patriarcado e Racismo. África do Sul, Brasil e Moçambique. Recife: Editora UFPE, 2018.p. 356-399.

ROCHA, S. et al. Catanas contra o neoliberalismo-patriarcal em tempos de Aids. Dossiê Mundos de Mulheres 2021: Pensamentos Feministas Afro-Moçambicanos - Ativismos. Florianópolis: Revista Estudos Feministas, V. 28. n.1, 2020. Disponivel em: <https://periodicos.ufsc.br/index.php/ref/article/ view/1806-9584-2020v28n168317/43534> Acesso em: 10 jan. 2021.

SAFFIOTI, H. I. B. Gênero, patriarcado, violência. São Paulo: Fundação Perseu Abramo, 2004.

SANTOS, Boaventura de Sousa. A trágica transparência do vírus. Sul 21, publicado em: $11 \mathrm{abr}$. 2020. Disponível em: https://www.sul21.com.br/opiniaopublica/2020/04/a-tragica-transparencia-do-virus-por-boaventura-de-sousa-santos/. Acesso em: 20 abr. 2021. 
SOARES, Raquel Cavalcante et al. Serviços de assistência especializada em HIV e Aids de Recife no contexto da contrarreforma da política de saúde. In: VIEIRA, Ana Cristina de Souza; ROCHA, Solange; BARBOSA FILHO, Evandro Alves (org.). HIV Aids e as teias do capitalismo, patriarcado e racismo: África do Sul, Brasil e Moçambique. Recife: UFPE, 2018. p. 295-322.

VIEIRA, A. Política de Saúde e HIV: direito à saúde e reformas regressivas. Revista Argumentum, Vitória, v. 10, n. 1, p. 72-83, jan./abr. 2018.

\section{Notas}

1 Doutoranda em Serviço Social (Programa de Pós-graduação em Serviço Social da Universidade Federal de Pernambuco - UFPE). Possui mestrado em Serviço Social (UFPE) e MBA em Gestão de Serviços Hospitalares (FCAP/UPE). Atualmente é Assistente Social do Hospital Universitário Oswaldo Cruz da Universidade de Pernambuco (UPE) e do Hospital Mendo Sampaio da Prefeitura do Cabo de Santo Agostinho. Tem experiência na área de Serviço Social, com ênfase em saúde, gênero, violência e HIV/Aids. N ORCID: https://orcid.org/0000-0003-4478-812X. E-mail: renata.cesar@upe.br

2 Pós-doutorando em Serviço Social pela Universidade Federal de Pernambuco, bolsista PNPD-Capes/Facepe. Doutor em Serviço Social pela UFPE (2016), com estágio de doutorado no exterior realizado no Departamento de Sociologia da University of Cape Town (2015-2016), África do Sul. Mestre em Serviço Social pela UFPE (2013) e Bacharel em Serviço Social (2009) também pela UFPE. NºRCID: https://orcid.org/0000-0002-2944-3388. E-mail: evealves85@yahoo.com.br

3 Professora Titular do Departamento de Serviço Social da UFPE. Doutora em Serviço Social pela PUC/SP (1992). Mestra em Serviço Social pela UFPE (1984). Fez Estágio Sênior com bolsa CNPq no Departamento de Sociologia da University of Cape Town (11/2013 a 03/2014). Bolsista de Produtividade CNPq 1B. Atua na Graduação e Pós-Graduação em Serviço Social da UFPE. Coordena o Projeto PrInt em Serviço Social (UFPE), iniciado em 2018. N ORCID: https://orcid.org/OOOO0002-8844-5375. E-mail: anacvieira12@gmail.com.

Aprovado pelo Comitê de Ética e Pesquisa da UFPE/Recife (CAEE 24494619.3.0000.5208) e pelo Comitê de Ética do Complexo Hospitalar Huoc/ Procape (CAEE 24494619.3.3001.5192).

4 No intuito de manter o sigilo sobre a identidade das entrevistadas, neste artigo, elas serão identificadas por meio do registro da entrevista (E) e a numeração correspondente à ordem cronológica de realização de sua entrevista, de 1 a 9.

5 Vírus da Imunodeficiência Humana.

6 Síndrome da Imunodeficiência Adquirida. 


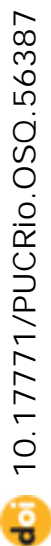

